\section{Dean L. P. Reinhold Matsson}

THE death last summer of Dean Reinhold Matsson, botanist, geneticist and churchman, at the relatively early age of sixty-eight years, is a distinct loss to rhodology and systematic botany in Europe.

Since the time of Linnæus, there has been a traditional line of systematic botanists in Sweden-Afzelius, Swartz, Hartman, Wahlenberg, Fries, Scheutz, Winslow, Almquist and Matsson-who have worthily upheld the torch first lighted by the Swedish father of systematic botany. The last two, Sigfrid Almquist and Dean Matsson, both specialized in the genus Rosa, and although their methods were so original and diverse from one another, their results were complementary.

Dean Matsson had the good fortune to be born on the famous island of Gotland and to attend school in the medieval town of Visby, well known as the 'city of ruins and roses'. The abundance of wild and naturalized roses in the district no doubt attracted the natural curiosity of a born researcher like Matsson who, though destined for the church, was by nature a naturalist and man of science. At the University of Uppsala he happily combined the studies of theology and botany, and at an early age, under the direction and supervision of the world-famous Belgian rhodologist, Prof. Crepin, he made a thorough study of the genus Rosa and afterwards continued his researches on his own original lines. His first scientific paper was published in $\mathbf{1 8 9 5}$ after two years' research in Gotland, Oland and Smaland, followed by papers in 1900 and 1901.

In the latter year, Matsson achieved a European reputation by his conspectus of Rosa in Neuman and Ahlfvengrens' "Flora of Sweden". Further contributions appeared in 1912, 1915 and 1916, culminating in his magnum opus of 1934-35, "Examen Rosarum Sueciæ", published in Kungl. Svenska Vetenskapsakademiens Handlingar, 14, No. 3, pp. 1-380 (1934), Stockholm. In the course of his numerous collections, Matsson accumulated an extensive herbarium of valuable rose material. Like all practical botanists, Matsson was an enthusiastic gardener and geneticist, and in his gardens at Hudiksvall, in the Province of Halsingland, he cultivated and experimented genetically with the forms of Rosa collected in his expeditions. In 1912, his remarkable genetical experiments in breeding various species of Caninæ true to type, after the flowers had been carefully castrated, demonstrated, for the first time on a large scale, the existence of apomixis in the Caninæ roses. This important fact, since confirmed genetically and cytologically, has led to the generally accepted theory of the hybrid origin of all the Caninæ species of Rosa.

Matsson also gave considerable assistance to Tackholm in identifying the material used by him in his important work on the chromosomes of Rosa, and he was fully alive to the advantages of combining genetical with systematic work.

As a systematic botanist, Matsson was more analytical than synthetical, and the permanent value of his svstematic work lies in his minute and accurate analyses of the character-combinations of the multitudinous forms, varieties, subspecies, and natural hybrids of the Caninæ species of Rosa.

\section{C. Hurst.}

\section{Mr. C. H. Jenkinson}

Much of the success of modern experimental research depends upon the quality of the instruments that are available, and it often happens that in the apportionment of credit for work done, the share of the workshop is comparable with that of the laboratory. Mr. C. H. Jenkinson, who died on March 6 after a short illness, was one of those artistic instrument-makers to whom science is in debt. He was trained in the works of the Cambridge Scientific Instrument Co. Nearly thirty years ago, he was given charge of the physics workshop of the University of Leeds. He made the first X-ray spectrometer. As the X-ray analysis of crystal structure developed and greater demands were made upon his skill, he never failed to respond, and to better the instructions given to him. Researches in various branches of physics, carried out at Leeds, at University College, London, and finally at the Royal Institution were greatly facilitated by his ingenuity in design, his judgment of material and his beautiful technique. In the reconstruction of the Royal Institution buildings his advice was of material value. $\mathrm{He}$ acted as a judge at the Physical Society's exhibitions in recent years. He will be sadly missed by the staff of the Davy Faraday Laboratory, and by all who are responsible for the effectiveness of the Royal Institution.

W. H. B.

WE regret to announce the following deaths:

Prof. Giuseppe Cesàro, formerly professor of mineralogy in the University of Liège, a pastpresident of the Belgian Academy of Sciences and correspondant for the Section of Mineralogy of the Paris Academy of Sciences.

Prof. H. M. Dawson, F.R.S., professor of physical chemistry in the University of Leeds, on March 11, aged sixty-three years.

Marcel Godchot, professor of chemistry and doyen of the Faculty of Sciences of the University of Montpellier and correspondant for the Section of Chemistry of the Paris Academy of Sciences, known for his work on the heterocyclic carbon compounds, on February 11, aged fifty-nine years.

Prof. A. M. Hocart, professor of social anthropology in the University of Cairo, on March 9, aged fifty-five years.

Dr. Ivan C. Jagger, senior pathologist in the Bureau of Plant Industry, U.S. Department of Agriculture, on February 16, aged forty-nine years.

Prof. C. M. Jessop, emeritus professor of mathematics in the University of Durham, on March 9, aged seventy-six years.

Prof. E. B. Wilson, For. Mem. R. S., Da Costa emeritus professor of zoology in Columbia University, on March 3, aged eighty-three years. 